\title{
Między czułością a okrucieństwem. Postać Kuby Rozpruwacza we wczesnej twórczości Ingmara Bergmana
}

\author{
Abstract \\ Between Tenderness and Cruelty. The Character of Jack the Ripper \\ in the Early Work of Ingmar Bergman
}

A short tale about one of Jack the Ripper's earliest childhood memories is the literary debut of Ingmar Bergman from 1944. The character of Jack is often considered as an early alter ego of the Swedish director that represents an extraordinary combination of tenderness and cruelty. As the narrator of the story, Jack reports on the event that took place in his childhood. The story of murder, which will repeat itself in his adult life, can be interpreted as a projection of the author's fears and anxieties, which were related, among other things, to the birth of his younger sister. Jack's character will reappear repeatedly in Bergman's subsequent works, especially in his early films from the 1940s, such as Crisis, and his presence will often be associated with the motifs of macabre, sadism but also love.

Keywords: Ingmar Bergman, Crisis, cruelty, Jack the Ripper.

Słowa klucze: Ingmar Bergman, Kryzys, okrucieństwo, Kuba Rozpruwacz.

Kuba Rozpruwacz, najbardziej znany seryjny morderca epoki wiktoriańskiej, który zasłynął przede wszystkim za sprawą wyjątkowego okrucieństwa, z jakim traktował swe ofiary, stosunkowo rzadko kojarzony jest z filmowymi dziełami Ingmara Bergmana. Jeszcze mniej znanym faktem jest, że postać ta po raz pierwszy pojawiła się w twórczości szwedzkiego reżysera nie na dużym ekranie, lecz w jego literackim debiucie pod tytułem Krótsze opowiadanie o jednym z najwcześniejszych wspomnień z dzieciństwa Kuby Rozpruwacza, opublikowanym w 1944 roku. Krótsze opowiadanie... to zarazem jedyna zachowana część cyklu Kaspernoveller, czyli opowieści o Kasprze, które autor pisał w wieku dwudziestu kilku lat. Jednak w całej jego twórczości tekst ten zajmuje miejsce dość wyjątkowe z co najmniej kilku powodów. Przede wszystkim, jak na niewprawnego pisarza, Bergman kreuje w nim z zadziwiającą literacką łatwością niezwykłą atmosferę, znaną 
widzowi choćby z filmu Tam, gdzie rosna poziomki, która łączy w sobie elementy magicznego realizmu, przeradzającego się stopniowo w napawający niepokojem ekspresjonistyczny sen. Równocześnie opowiadana historia, w szczególności za sprawą głównego bohatera, skupia w sobie niczym w soczewce tematy i motywy, które przez następne kilkadziesiąt lat reżyser będzie rozwijał w swych najważniejszych filmowych dziełach. To właśnie w swym literackim debiucie Bergman po raz pierwszy poruszy temat czułości splatającej się z sadyzmem czy wręcz dosłownym rozczłonkowaniem ludzkiego ciała, co - jak okaże się w późniejszych dziełach reżysera - będzie niezmiennie wiązało się u niego z chęcią dotarcia do ludzkiej tajemnicy.

Krótsze opowiadanie... charakteryzuje się trzypoziomową formą szkatułkową, a jego głównym bohaterem jest tytułowy Kuba, który relacjonuje swemu przyjacielowi Theobaldowi pewną historię: którejś nocy jego kochanka z przerażeniem odkryła w starym zegarze niewielkiego, liczącego ledwie trzydzieści centymetrów, człowieczka. Pojawił się on, by przypomnieć makabryczne morderstwo dokonane w dzieciństwie przez głównego bohatera na synu karzełka. W tym momencie oniryczna atmosfera opowieści jeszcze bardziej się zagęszcza, zaś czytelnik, wkraczając na drugi poziom narracji, dowiaduje się, że pewnej nocy, kilkadziesiąt lat wcześniej, trzyletni wówczas Kuba usłyszał żałosny pisk leżącej na podłodze maleńkiej dziewczynki. Przepełniony czułością dla tej niewinnej istotki postanowił zabrać ją z sobą do łóżka i otoczyć opieką, co opisuje następującymi słowami:

Omal nie oszalałem ze szczęścia (...). Będę mógł zbudować dla niej mały domek w pudle z zabawkami, będę mógł ją karmić, będziemy mogli wychodzić na spacer, a ona będzie siedziała w małym wózeczku z żółtymi szprychami (...). Poczułem, że mięknę od środka, tak jakbym miał się roztopić, jakby moje małe serduszko miało pęknąć wezbrane łzami szczęścia. Instynktownie ściągnąłem koszulkę nocną i leżałem nagi, patrząc na jej miniaturową figurkę ${ }^{1}$.

Z taką wizją emocjonalnej więzi chłopiec zasypia, a budzi go dopiero wspomniany wcześniej karzełek - ojciec obiektu miłości Kuby, pragnący jak najszybciej oddalić się ze swym dzieckiem, które całkiem nieoczekiwanie okazuje się przebranym za dziewczynkę chłopcem. Wiadomość ta powoduje jednak w bohaterze nagły przypływ obrzydzenia do samego siebie, co wiąże się z jego dwuznacznym uczuciem do chłopca-karzełka. W wyniku gwałtownie wzbierającego w nim gniewu miażdży on w dziecięcej piąstce ciało chłopczyka, a następnie odcina mu głowę i pozbywa się jego ciała, wkładając je do piórnika i zakopując w ogrodzie. Co ciekawe, w podobny sposób dorosły już Kuba pozbędzie się również swej kochanki, której poćwiartowane zwłoki zostawi w hotelu Savoy. Choć tak naprawdę trudno mu w obydwa morderstwa uwierzyć, gdyż pod koniec tej opowieści sam je niejako podważa.

Postać Kuby Rozpruwacza z Krótszego opowiadania..., która uosabia niezwykłe połączenie czułości i okrucieństwa, a jednocześnie może być postrzegana jako

1 I. Bergman, Krótsze opowiadanie o jednym z najwcześniejszych wspomnień z dzieciństwa Kuby Rozpruwacza, thum. T. Szczepański, „Kino” 1991, nr 5, s. 9-11. 
projekcja lęków i obsesji samego reżysera, powróci jeszcze w swej literackiej wersji w dramacie zatytułowanym Kuba u aktorów ${ }^{2}$ oraz w krótkim nieopublikowanym tekście Śmierć Kuby. Z kolei na dużym ekranie widz pozna go przede wszystkim jako Jacka w niezbyt pozytywnie przyjętym przez krytykę filmowym debiucie Bergmana pod tytułem Kryzys. Obraz ten możemy najprościej przedstawić jako historię naiwnej dziewczyny z głębokiej prowincji, uwiedzionej przez grzeszne życie miasta. Na pierwszy rzut oka główną bohaterką jest tu właśnie prostolinijna Nelly, która znudzona wiejskim życiem i naprzykrzającym się jej podstarzałym adoratorem przeprowadza się do swojej biologicznej matki Jenny. Opuszczenie bezpiecznego domu wiąże się jednak z tym, że niemal od razu wpada ona w ręce uwodzicielskiego, a zarazem nieco demonicznego kochanka matki, Jacka, który - tak samo jak zostało to opisane w opowiadaniu o Kubie mieszka pod schodami w starym zrujnowanym zamku, gdzie z wielkiego okna ma widok na łąkę, zatokę i dwa kominy fabryczne ${ }^{3}$. I to właśnie Jack okaże się tu postacią niewątpliwie najciekawszą i najbardziej niejednoznaczną, której sama już obecność budzi w widzu pewien niepokój. Co ciekawe, jest on także jedynym bohaterem, którego reżyser dopisał do oryginalnego scenariusza radiowej sztuki autorstwa Lecka Fischera, na której opiera się film.

Podobnie jak literacki Kuba, Jack w równym stopniu czerpie niekłamaną przyjemność z opowiadania innym najbardziej nieprawdopodobnych historii na swój temat. W Kryzysie makabryczne wspomnienie z dzieciństwa, które znamy z wczesnego opowiadania Bergmana, zastępuje historia upozorowanego na wypadek zatrucia gazem kobiety w ciąży, opowiadana przez bohatera w taki sposób, że niełatwo rozeznać, czy właśnie dokonuje on autentycznego wyznania, czy też świetnie się bawi, wykorzystując łatwowierność słuchacza. Grany niezmiennie przez Stiga Olina Jack powróci następnie w kilku innych dziełach Bergmana z przełomu lat 40. i 50., między innymi w epizodycznej kreacji w Mieście portowym z 1948 roku, gdzie jego rola ograniczy się wyłącznie do uwiedzenia wyrzuconej z domu młodocianej Berit. Filmowy Kuba jest u Bergmana najczęściej eleganckim, charyzmatycznym młodym mężczyzną o ciemnych zaczesanych gładko włosach i nienagannych na pierwszy rzut oka manierach, który skrywa zarazem jakąś pociągającą tajemnicę, roztaczając wokół siebie diaboliczny magnetyzm. Tak naprawdę dwuwymiarowość tego bohatera polega na tym, że pod płaszczykiem kokieterii kryje on męczącą go melancholię, zagubienie i niedające spokoju wyrzuty sumienia. Podobnie jak sam reżyser w tamtym okresie, Jack jest początkującym, a jednocześnie zakochanym w sobie artystą, który w jednej ze scen Kryzysu z tkliwością całuje własne zdjęcie. Już sama jego obecność na ekranie niechybnie wróży kłopoty, a zarazem motywuje filmową akcję. To Jack popchnie pozostałych bohaterów do zmiany i sprowokuje ich do przemyśleń i zachowań, które bez jego udziału byłyby niemożliwe.

Stan rozdarcia między niczym nieskrępowaną wolnością, przyjemnością i podążaniem za chwilowym porywem serca a obowiązkiem i odpowiedzialnością jest

2 Dramat przełożony na język polski przez Tadeusza Szczepańskiego ukazał się w czasopiśmie „Dialog”. I. Bergman, Kuba wśród aktorów, tłum. T. Szczepański, „Dialog” 2009, nr 1, s. 72-98.

3 I. Bergman, Krótsze opowiadanie..., s. 9-10. 
czymś, co pozwala nam myśleć o Jacku jako o postaci bardzo niejednoznacznej. $Z$ jednej strony daje się on poznać jako bawidamek i kpiarz. Zaraz po jego wkroczeniu w życie młodej Nelly widz orientuje się, że nie można ufać ani jednemu jego słowu, gdyż jako mitoman uwielbia opowiadać i bawić innych, karmiąc się naiwnością swoich słuchaczy. Z drugiej strony, w najbardziej nieoczekiwanych momentach jego blaga zmienia się w autentyczne i przepełnione bólem wyznanie. Jedną z ważniejszych scen filmu, gdzie bodaj po raz pierwszy Jack wychodzi z roli kuglarza i manipulatora, jest jego rozmowa z Ingeborg, adopcyjną matką Nelly. W tej relacji nie ma on tak naprawdę nic do ugrania i choć początkowo próbuje swoim zwyczajem zrobić na kobiecie dobre wrażenie, oferując pomoc i częstując słodyczami, po chwili zrzuca swoją nieodłączną maskę (tu raczej kapelusz!) blagiera i objawia twarz człowieka udręczonego i całkowicie rozdwojonego: „Nie potrafię kochać nikogo poza sobą. Ale Nelly jest kimś realnym. Mógłbym potraktować ją jako kotwicę rzeczywistości. Dla własnego dobra. To czysto egoistyczny punkt widzenia" - powie Jack, a jego wyznanie możemy postrzegać jako swoisty klucz do odczytania tej postaci, a także moment pozwalający zobaczyć w niej odbicie samego Bergmana, który już po latach wyzna w jednym z wywiadów:

Nie znam tej osoby, jaką byłem przed czterdziestu laty (...). Gdy sądziłem, że jestem atakowany, odgryzałem się jak przerażony pies. Nie ufałem nikomu, nie kochałem nikogo, nie tęskniłem za nikim. Byłem opętany seksem, który zmuszał mnie do ustawicznych wiarołomstw i przymusowych postępków, ustawicznie dręczony pożądaniem, strachem, lekiem i wyrzutami sumienia. Byłem zatem samotny i wściekły. Praca w teatrze dawała pewną ulgę w napięciu, które opuszczało mnie tylko na krótkie chwile w pijaństwie albo w orgazmie. Wiedziałem, że mam zdolność przekonywania, że sprawiam, iż ludzie robią, co chcę, że roztaczam wokół się jakiś urok, który potrafię włączać i wyłączać według upodobania ${ }^{4}$.

Kryzys powstaje właśnie w momencie, gdy reżyser ma porzucić swoją pierwszą żonę Else Fisher oraz córkę Lenę dla Ellen Lundström, którą po pięciu latach małżeństwa także porzuci, z czwórką dzieci, dla innej kobiety. Lata 40. i początek 50. to chyba najbardziej burzliwy czas w życiu szwedzkiego reżysera - zarówno zawodowym, jak i osobistym. Wplątuje się on nieustannie w nowe romanse, a w tym samym czasie próbuje swoich sił w teatrze oraz filmie, co często kończy się niepowodzeniem. Przyjaciel Bergmana Jörn Donner, zauważając w postaci filmowego Jacka odbicie samego reżysera, opisuje go jako marionetkę, stworzenie, które jest zdolne kochać tylko siebie, jako ,żyjącego martwego człowieka"5. Ustami Jacka z Kryzysu Bergman otwarcie przyzna, że tym, co powodowało nim w życiu, jest czysty egoizm i chęć zaspokojenia swoich potrzeb, pomimo dojmującego poczucia winy. ,Jenny żeruje na mnie. Ja żeruję na Nelly. To iście szatańskie” wyzna w jednej ze scen bohater, zauważając, że często ludzkie relacje charakteryzuje fakt, iż każdy wykorzystuje drugiego do swoich celów. Co ciekawe, słowa te zostaną odebrane w całkiem nieoczekiwany sposób przez Ingeborg, przybraną matkę Nelly, która całe swoje życie poświęciła jej wychowaniu, przekonana, że robi to wyłącznie z miłości i dobroci serca. Jak zauważa Donner, Kryzys poka-

4 I. Bergman, Laterna magica, thum. Z. Łanowski, Warszawa 1991, s. 141.

B. Young, The Persona of Ingmar Bergman: Conquering Demons through Film, London 2015, s. 47. Tłumaczenie J. Kryg. 
zuje, że to jednak ,praktyczna korzyść oraz ciasny egoizm ostatecznie kierują zachowaniem człowieka"'. Ingeborg skieruje tę prawdę również na siebie, stawiając fundamentalne pytanie o to, czy tak naprawdę każda ludzka potrzeba miłości i przywiązania nie wypływa z czystego egoizmu. Dręczona sennym koszmarem bohaterka nie może znieść myśli, że jej troska i miłość w stosunku do córki, które do tej pory uważała za całkowicie bezinteresowne, mogłyby w rzeczywistości być podyktowane strachem przed samotnością i chęcią zaspokojenia własnego głodu emocjonalnego. Autor nie daje tu jednak jednoznacznej odpowiedzi na to niedające spokoju bohaterce pytanie. Zwraca on natomiast uwagę na fakt, że potrzeba intymności i bliskiego kontaktu z drugim człowiekiem bardzo często przeradza się w okrucieństwo, co doskonale obrazuje już historia trzyletniego Kuby, który w krwawy sposób morduje ukochanego karzełka.

Okrucieństwo jest jedną z cech, które łączą bohatera Krótszego opowiadania... z jego dorosłym filmowym wcieleniem. Mimo że Bergman zaznaczył we wstępie do swej opowieści, iż przedstawionego przez niego bohatera „nie należy mylić z jego angielskim imiennikiem" ", to zarówno Kuba, jak i Jack, nie bez związku ze znanym seryjnym mordercą, śmiało obchodzą się z nożem, którym bez wahania odcinają głowy swym ofiarom. I to właśnie owo rozczłonkowanie ciała, odcięcie twarzy i oddzielenie głowy od tułowia wydaje się w przypadku tej postaci niezwykle ważne. Twarz bowiem, jako niewątpliwie jeden z ważniejszych i najczęściej pojawiających się bergmanowskich motywów, ściśle łączy się u niego z jakąś tajemnicą. Nie jest ona po prostu jedną z części ciała, lecz swoistą furtką do wnętrza ludzkiej osobowości. Również w kontekście opowieści o Kubie Rozpruwaczu twarz jest traktowana właśnie jako miejsce manifestacji prawdy, które nawet za cenę przekroczenia bariery fizyczności może pomóc w rozwiązaniu tajemnicy o drugim człowieku. Poprzez gesty przemocy, gwałt czy rozczłonkowanie twarzy bohaterowie dzieł Bergmana często usiłują wedrzeć się wewnątrz kogoś tak, by zaspokoić w końcu swą chorobliwą żądzę poznania. Tego rodzaju ciekawość, realizująca się właśnie poprzez chęć przemocowego rozdarcia ludzkiej twarzy, by dotrzeć do wnętrza osobowości, jest obecna choćby w filmie pod znamiennym tytułem Twarz. Głównym bohaterem jest tu grany przez Maxa von Sydowa członek wędrownego Teatru Magnetycznego kuglarz Emanuel Vogler, który reprezentuje nieuchwytny i niedający się łatwo zdefiniować świat sztuki. Jako niemy prestidigitator mówi on wyłącznie za pomocą swoich sztuczek, podobnie jak artyści zwykli przemawiać do odbiorców poprzez swoje dzieła. Bergman przy pomocy postaci magika oraz jego symbolicznego oponenta - lekarza Vergerusa - przeciwstawia tu dwa sposoby poznania: pierwszy z nich jest metafizyczny i intuicyjny, namawia do zawierzenia temu, co niewidoczne, zaufania wyobraźni, halucynacji czy magicznej sztuczce. Drugi natomiast, dzięki metodzie szkiełka i oka, całkowicie neguje istnienie elementu nadprzyrodzonego, dążąc do uzyskania namacalnych dowodów istnienia. Niema i niewyrażająca niemal żadnych emocji twarz Voglera jest dla ograniczonego przez logikę medycyny Vergerusa

\footnotetext{
6 Ibid.

I. Bergman, Krótsze opowiadanie..., s. 9.
} 
czymś, co prowokuje i budzi silną obsesję ujawnienia tego, co niepoznane. Jak zauważa Anna Szyjkowska:

Magik uosabia tajemnicę transcendencji, lekarz pragnie go zdemaskować w sposób dosłowny: zdjąć jego twarz. Stwierdza, że tym, co go naprawdę interesuje, jest jego fizjonomia. Chciałby wyjąć mu oczy, rozkroić głowę i zajrzeć do mózgu. Pragnie rozpruć tajemnicę twarzy, rozczłonkować ją, zbadać i zamienić w mięso ${ }^{8}$.

Jednocześnie twarz ludzka często jest u Bergmana przeciwstawiona twarzy sztucznej, należącej do manekina lub marionetki. Takie zestawienie dokonuje się wprost właśnie w Kryzysie, w jednej z końcowych, a zarazem kluczowych dla rozwoju akcji scen, o której sam reżyser mówił, że z perspektywy czasu jest jedynym cokolwiek wartym fragmentem filmu. Akcja rozgrywa się w salonie piękności, w którym po przeprowadzce do miasta pracuje Nelly. Jest dość późno, dziewczyna sprząta po całym dniu i gasi światła. Salon wypełniony jest głowami manekinów, a ku jej przerażeniu przez witrynę do środka salonu zagląda nieruchomo stojący mężczyzna w kapeluszu. Niespodziewanie zjawia się Jack. Rozgląda się, przypatruje manekinom, a po chwili mówi do Nelly: „Dziwne jest to miejsce, prawda? Wszystkie te odcięte głowy (...). Chciałbym tu przyjść, gdy będzie dużo kobiet. Spojrzałbym w ich oczy, mówiąc: no, teraz powiedzcie wszystko Jackowi”. Jak możemy zauważyć, manekiny, oprócz oczywistej aluzji do zniewolenia ludzkiego losu, symbolizują tu kłamstwo lub pozę przyjmowaną w relacjach z innymi. Plastykowa głowa lalki, którą bawi się Jack, budzi w nim niemal od razu chęć dociekania prawdy. W nieruchomej marionetce dostrzega pozór czy też pewną konwencję, w której bohaterowie muszą na co dzień funkcjonować. I podobnie jak doktor Vergerus w filmie Twarz, Jack pragnie przełamać tę konwencję właśnie przemocą fizyczną. Odcięcie głowy to jedyna droga poznania i odkrycia tego, co skrywa się pod maską. Tę logikę potwierdza skądinąd już pierwsza scena z udziałem Jacka, gdy przybywa on za swą kochanką Jenny na prowincję i zaskakuje ją w hotelu. Chcąc dowiedzieć się, w jakim celu kobieta przyjechała do miasteczka, wydobywa z kieszeni scyzoryk i w całkiem beztroski sposób przesuwa nim po jej szyi, mówiąc: „No, powiedz, jakie ciemne interesy sprowadzają cię do tej dziury. Wyśpiewaj wszystko, bo poderżnę ci gardło i schowam do kufra". Ta groźba niemal od razu budzi skojarzenie z morderstwem popełnionym przez literackiego Kubę, który ćwiartuje kochankę Marię, a jej ciało zostawia w walizce. W Kryzysie Jenny wcale nie jest jednak zaskoczona postępowaniem mężczyzny, tak jakby było ono dla niej całkowicie zwyczajne, a nawet przewidywalne. Mogłoby się zatem wydawać, że bohater zwykł zachowywać się w ten sposób za każdym razem, gdy pragnie poznać jakiś jej sekret. Dla Jacka twarz jest więc maską prawdy, a tę można wydobyć jedynie poprzez dosłowne dotarcie do jej źródła - przedzierając się przez powłokę skóry, aż do wnętrza.

Jednak maska jest zarazem czymś, czego Jack sam nie potrafi się pozbyć. $\mathrm{Z}$ jednej strony bezwzględnie próbuje zedrzeć z innych wszelkie ślady pozoru, niejednokrotnie uciekając się do fizycznej przemocy, lecz jednocześnie sam nie jest w stanie odrzucić własnej wystudiowanej pozy i zdobyć się choćby na cień

\footnotetext{
8 A. Szyjkowska, Po-twarz. Przekraczanie widzialności w sztuce i filozofii, Gdańsk 2016, s. 45.
} 
szczerości w swym zachowaniu. Rozmowa między Nelly a Jackiem w salonie piękności, która bezpośrednio poprzedza samobójstwo bohatera, jest momentem, gdy po raz pierwszy próbuje on wyjść poza ciasne ramy roli, którą dla siebie wybrał. Wydaje się, że potwierdza to już sama zmiana jego wyglądu: jego włosy są nieuczesane, twarz nieogolona, a on sam rozchełstany. Gdy zaniepokojona Nelly zauważa tę zmianę, Jack zarzuca jej, że sama nie jest już sobą. I w rzeczywistości ma rację - Nelly pracująca w wielkim mieście ma w sobie już niewiele z prostodusznej wiejskiej dziewczyny, którą poznaliśmy na początku filmu. Jej gesty, elegancki stój i fryzura świadczą o tym, że stała się jedną z marionetek, założyła maskę, która wyraźnie drażni Jacka. I tu kolejny raz bohater ucieka się do przemocy: popycha dziewczynę i szarpie ją, chcąc zmusić do odrzucenia wyuczonej roli. Chwilę potem demaskuje sam siebie, mówiąc: „Nie będę już robił dobrej miny do złej gry. Zabiję się! To tylko gra”. Motyw zniewolenia w przypadku Jacka jest jednak co najmniej dwuznaczny: z jednej strony bohater jest zakochany we własnym zmanierowaniu i tożsamości, jaką dla siebie wykreował. Prawdziwą przyjemność odczuwa też wówczas, kiedy sam może pociągać za sznurki. Gdy wywołuje skandal na balu towarzyskim, z zachwytem przypatruje się powstałemu zamieszaniu, mówiąc: „Co za banda marionetek. I czyja to sprawka? Moja!”. Z drugiej strony jest świadomy, że kiedy wejdzie się w jakąś rolę, nie można się już od niej uwolnić. Znamienne jest też to, jak Bergman komentuje los bohatera w swoim dzienniku z tamtego okresu, zauważając, że ,najstraszniejszą rzeczą jest to, że czarny charakter Jack jest nieustannie zmuszany do rozdzierania swojego serca i ukazywania prawdziwego oblicza publiczności, która za to płaci"”. Przyzwyczajony do egzaltacji Jacka widz nie traktuje jednak poważnie jego zapowiedzi samobójstwa, przypuszczając, że jest ono jedynie kolejną próbą wymuszenia współczucia i czułości łatwowiernej Nelly. Scena w salonie piękności istotnie kończy się fizycznym zbliżeniem bohaterów, które poprzedza wyznanie miłości Jacka, po czym kamera robi znaczące zbliżenie na twarz jednego z manekinów otaczających zewsząd tę dwójkę, tak jakby słowa Jacka były mimo wszystko kolejnym potwierdzeniem gry, z której nie jest on w stanie się wyzwolić, a jedyną ucieczką miałaby być śmierć. W tym momencie przypominamy sobie słowa, które skierował on do Nelly już na samym początku: „Pewnego dnia opuszczę teatr marionetek, by wkroczyć w ciemność. Sprężyna pęknie, wszystko się rozpadnie, a ludzie powiedzą: ten Jack... nieważne, co się z nim stało”. W tym kontekście bardzo symboliczne jest też miejsce śmierci mężczyzny, którego zakrwawione ciało zostaje odnalezione przed drzwiami teatru na mokrej i ciemnej ulicy, tak jakby samobójstwo było ostatnią rolą, jaką miał jeszcze odegrać. Taki koniec zapowiadany jest także słowami, które wypowiada on wcześniej do matki dziewczyny, stwierdzając: „Jeśli tylko bierzemy, nie dając nic w zamian, czeka nas najsurowsza kara”. Tym samym poprzedzające finałową scenę fizyczne zbliżenie z Nelly możemy odczytywać jako bezpośredni powód kary, którą bohater sam sobie musi w końcu wymierzyć, tak jak wcześniej to zapowiedział.

9 Bergman Notebook, notatka była częścią wystawy w Swedish Film Institute w 2007 roku [za:] G. Macnab, Ingmar Bergman: The Life and Films of the Last Great European Director, London 2009, s. 48. Tłumaczenie J. Kryg. 
Jednak to, czy śmierć rzeczywiście stanowi ostateczne wyzwolenie z przyjętej czy też odgórnie narzuconej roli, nie jest tu jednoznaczne. Bergman podaje ten fakt w wątpliwość już choćby w krótkim tekście pod tytułem Śmierć Kuby Rozpruwacza, który napisał najprawdopodobniej około 1942 roku. Możemy tam przeczytać:

Pewnego dnia Kuba Rozpruwacz umarł. Wszyscy w teatrze uważali, że to bardzo smutne, i zebrali pieniądze na wieniec, przyszykowali się, by iść na pogrzeb w cylindrach, wypożyczonych smokingach, czarnych butach, białych szalikach i czarnych skarpetkach. Ale Kuba leżał w domu w łóżku, przykryty białym prześcieradłem, zgorzkniały i zimny. Jego dusza nie odleciała bowiem daleko, lecz pozostała, przyklejona do tego krnąbrnego człowieka. Dawała jednak tak nikłe znaki swojej obecności, że wszyscy, łącznie z lekarzem, wierzyli, że Kuba jest martwy. Ale Kuba słyszał i widział wszystko. Nie tak, jak Kasper, Subba czy reżyser - ale jak widzi i słyszy małe dziecko, kwiat czy coś podobnego ${ }^{10}$.

Podobne uwięzienie będzie przeżywał także główny bohater dramatu Kuba wśród aktorów, który po likwidacji teatru przezjego dyrektora zostanie w nim zamknięty. Tym razem uwięziony więc nie w ciele, lecz w teatrze, Kuba dosłownie rzuca się na scenę, błagając patrzącego na niego z góry okrutnego reżysera Skarpa o uwolnienie. Jak możemy się domyślić, Skarp jest tu symbolicznym Bogiem, który nawet po śmierci nie pozwala człowiekowi opuścić teatru marionetek.

Powiązane z postacią Kuby Rozpruwacza wątki będą oczywiście rozwijane przez Bergmana w kolejnych filmach, lecz w mniej dosłowny sposób, zaś sama postać Kuby powróci po latach nieobecności wraz z dręczącymi go namiętnościami i obsesjami już pod innym imieniem w filmie $Z \dot{z} y$ cia marionetek. Obraz ten jest ciekawym powrotem do najważniejszych tematów, które Bergman poruszył prawie czterdzieści lat wcześniej w Krótszym opowiadaniu... Najciekawsze jednak w tym zrealizowanym w języku niemieckim jednym $\mathrm{z}$ ostatnich filmów szwedzkiego reżysera jest jednak nie tytułowe odwołanie do motywu theatrum mundi, lecz próba dotarcia do źródeł okrucieństwa, które po raz pierwszy zamanifestowało się już w momencie, gdy trzyletni Kuba pod wpływem silnych emocji najpierw zmiażdżył, a potem odciął głowę ukochanemu karzełkowi. W Życiu marionetek Kuba nie jest już jednak Jackiem, lecz przybiera nazwisko znanego widzowi ze Scen z życia matżeńskiego Petera Egermana, tym razem granego przez niemieckiego aktora Roberta Atzorna. W postaci Egermana Bergman zdaje się szukać ostatecznej odpowiedzi na pytanie, skąd między dwojgiem bliskich sobie, kochających się ludzi bierze się tak silna potrzeba zadawania cierpienia. W tym przypadku żądza krwi bohatera, który snuje przerażającą wizję zamordowania własnej żony, nie wypływa bowiem z chwilowej namiętności czy jednoznacznej nienawiści w stosunku do niej. Przeciwnie, Egerman bardzo spokojnie opowiada o tym prześladującym go od dwóch lat pragnieniu mordu swojemu psychoanalitykowi. Tak oto wyobraża sobie tę scenę, w której wraz z żoną stoją naprzeciw lustra:

10 I. Bergman, En dag dog Jack Uppskäraren, http://www.ingmarbergman.se/verk/en-dag-dogjack-uppskararen (dostęp: 1.06.2018). Tłumaczenie J. Kryg. 
Ja stoję za nią, w prawej ręce trzymając brzytwę. Ona patrzy na mnie cały czas [w lustrze] i w końcu widzi mnie naprawdę. Ledwo dostrzegalny uśmiech błąka się na jej ustach. Czuję jej nieznaczne poruszenie, ledwo wyczuwalny puls na jej gardle.

Zignorowany przez lekarza Egerman zrealizuje swoje marzenie poprzez uduszenie i pośmiertny gwałt na prostytutce, co będzie miało miejsce już w pierwszej scenie filmu, jako jedynej zrealizowanej w kolorze. Ciąg dalszy filmu $Z \dot{z} y c i a$ marionetek będą zaś stanowiły retrospekcje z życia małżeńskiego Petera i Katariny oraz policyjne zeznania ich bliskich. Szczególnie wyznanie matki głównego bohatera wydaje się w tej historii dość znaczące, gdyż możemy doszukać się w nim kilku elementów znanych już z Krótszego opowiadania..., które pozwalają jednocześnie wysnuć przypuszczenie, że odnoszą się w równym stopniu także do osobistych wspomnień z dzieciństwa samego reżysera. Kobieta opowiada, między innymi, o bliskiej relacji syna z trzy lata młodszą siostrą, z którą razem bawili się lalkami i wystawiali teatrzyk marionetek. Przedstawia go także jako lękliwe i wrażliwe dziecko, bojące się ciemności, koni, psów i ptaków. Podobne opisy swego dzieciństwa przedstawiał sam Bergman, nie ukrywając własnej zażyłości z młodszą siostrą Margaretą ani faktu, że znaczna część jego młodości była naznaczona wielką tęsknotą za miłością niedostępnej matki, która z najdrobniejszego powodu zamykała go ku jego przerażeniu w szafie i ganiła za to, że bawi się lalkami i zachowuje jak dziewczynka ${ }^{11}$. Rodzące się z tego powodu poczucie winy możemy dostrzec już w Krótszym opowiadaniu..., gdy Kuba, odkrywszy prawdziwą płeć karzełka, przeżywa poczucie winy i wstyd z powodu okazanej mu czułości, a jednocześnie ból wywołany odrzuceniem. Bergman tak opisuje to zdarzenie w swej opowieści: „I wtedy (...) coś stało się z moim trzyletnim serduszkiem. Coś strasznego, okropnego i upokarzającego. Ogarnął mnie wstręt do samego siebie, do mojej nagości, do mojej czułości, do śnionych przed chwilą fantazji"12. To w tym momencie w chłopcu budzą się okrucieństwo i wola zemsty, co pozwala upatrywać ich przyczyny właśnie w doznanym upokorzeniu. Fragment ten pokazuje, jak szybko i radykalnie tkliwość przeradza się w sadyzm, miłość w nienawiść, a bliskość w chęć unicestwienia. Dla Bergmana najbardziej fascynująca jest owa dwoistość - fakt, że tak przeciwstawne sobie emocje mogą wypływać z jednego źródła. Refleksję tę w sposób dosłowny podejmuje również Tim, homoseksualny przyjaciel Petera Egermana, który następująco opisuje to uczucie:

Podchodzę do lustra, wpatruję się w swoją twarz, która stała się dla mnie tak zwyczajna, i dochodzę do wniosku, że ta mieszanina ciała, krwi, nerwów i kości mieści w sobie dwa całkowicie różne pragnienia. Marzenie o bliskości, czułości, przebaczeniu, o wszystkim tym, co żywe. A z drugiej strony - przemoc, perwersja i groza śmierci.

Przedstawiony dualizm jest charakterystyczny również dla relacji małżeństwa Egermanów. Z jednej strony Katarina opowiada o niezwykle silnie łączącej ich więzi, mówiąc: „Peter jest częścią mnie. Noszę go w sobie dokądkolwiek idę. Jest we mnie. Nigdy nie czułam tego w stosunku do kogokolwiek innego". Jednak

11 T. Szczepański, Zwierciadło Bergmana, Gdańsk 1999, s. 31.

12 I. Bergman, Krótsze opowiadanie..., s. 11. 
wzajemne upokarzanie zdaje się dla nich czymś naturalnym: uderzenie w twarz przejawem bliskości fizycznej, a wrogość - formą przywiązania. Kluczem do odpowiedzi na pytanie o przyczynę rodzącego się w stosunku do kochanej osoby okrucieństwa może być ta oto z pozoru niewinna opowiastka jednego z bohaterów filmu Skandal, którym Bergman zadebiutował w 1944 roku jako scenarzysta:

Wielki kot siedział przed domem, wygrzewając się w słońcu. Podszedłem do niego i pieszczotliwie przemówiłem. Otarł się o mnie i zamruczał. Nachyliłem się i pogłaskałem go po grzbiecie. Nagle ugryzł mnie w rękę. Wyglądał tak, jakby się zawiązał w supeł. Wbił się wszystkimi dwudziestoma szponami w moją rękę, trzymając się jej wściekle i wwiercając się w nią zębami. Nigdy nie zapomnę mojej paniki. Chyba krzyknąłem. Jak myślisz, co zrobiłem? Zanurzyłem kota, rękę i całe ramię w stojącej w pobliżu beczce z wodą. Kot zesztywniał w konwulsjach. Utopił się, ale ręki nie puścił (...). Oto jak należy się zachowywać. Ugryźć i trzymać. Nie puszczać. Jeśli ja nie ugryzę, to ty ugryziesz, więc gryzę pierwszy ${ }^{13}$.

Ta prosta historia jest tak naprawdę opowieścią o odrzuceniu, upokorzeniu i dominacji, będącymi źródłem okrucieństwa, zadawanego przez bohaterów jego filmów tym, którzy pozwolili sobie w stosunku do nich na takie zachowania. Podobnie jak bohater Skandalu, trzyletni Kuba, odrzucony przez obiekt swej autentycznej i spontanicznej czułości, a zarazem upokorzony swym mylnie ulokowanym uczuciem, posuwa się do bezdusznego morderstwa, chowa swą ofiarę w piórniku, a następnie zakupuje ją w ziemi, próbując wymazać z pamięci ten zawstydzający incydent, tak jakby nigdy nie miał on miejsca. Z kolei w Życiu marionetek Peter Egerman, w którym wyraźnie odbija się echo zachowań Kuby, już w dzieciństwie został naznaczony przez silnie dominującą matkę, której rolę przejęła potem jego pewna siebie i próbująca podporządkować go sobie żona Katarina. Również w osobistych wspomnieniach Bergmana możemy odnaleźć niejeden fragment mówiący o cierpieniu, jakie przeżywał, starając się o względy swej zimnej i niepodatnej na jego uczuciowość matki, która chłopięcą wrażliwość uważała bardziej za przejaw niemęskiej słabości. A zatem zamordowanie i analny gwałt prostytutki, która skądinąd dzieli z żoną bohatera Życia marionetek to samo imię, możemy interpretować nie jako dowód na utajony biseksualizm Egermana, co sugeruje w filmie jego psychoterapeuta, lecz raczej jako bunt wobec kobiecej dominacji i karę za doznane poniżenie. Obnażenie słabości, odrzucenie względów czy upokorzenie są przeżyciami, które chyba najsilniej wpływają na psychikę bergmanowskich bohaterów, zaś Kuba Rozpruwacz niejako ucieleśnia to najbardziej radykalne następstwo budzącej się w nich żądzy okrucieństwa.

Jak możemy zauważyć, literacki debiut Bergmana stanowi źródło wielu motywów, które autor będzie rozwijał w trakcie swojej wieloletniej filmowej działalności. Samej postaci Kuby Rozpruwacza, która stosunkowo rzadko kojarzona jest z jego twórczością, łatwo jest natomiast przypisać zbiór cech, jakie odnajdziemy nie tylko u jego kinowego imiennika Jacka, lecz także u wielu innych bohaterów. Warto jednak zaznaczyć, że twórcze tematy najważniejszych dzieł Bergmana, takich jak choćby Persona, Milczenie czy Tam, gdzie rosna poziomki, możemy

13 I. Bergman, Hets, „Filmjournalen” 1944, nr. 51 [za:] T. Szczepański, op. cit., s. 77-78. 
odnaleźć już w na ogół mniej znanych lub nieco marginalizowanych pierwszych filmowych i literackich utworach, w których to właśnie Kuba Rozpruwacz po raz pierwszy ucieleśnia niemożliwe do pogodzenia z sobą, a jednak istniejące w jednym ciele: gorączkę gniewu, ból samotności i tęsknotę za bliskością.

\section{Bibliografia}

Bergman I, En dag dog Jack Uppskäraren, http://www.ingmarbergman.se/verk/en-dag-dog-jack-uppskararen (dostęp: 1.06.2018).

Bergman I., Krótsze opowiadanie o jednym z najwcześniejszych wspomnień z dzieciństwa Kuby Rozpruwacza, tłum. T. Szczepański, „Kino” 1991, nr 5.

Bergman I., Kuba wśród aktorów, tłum. T. Szczepański, „Dialog” 2009, nr 1.

Bergman I., Laterna magica, thum. Z. Łanowski, Warszawa 1991.

Macnab M., Ingmar Bergman: The Life and Films of the Last Great European Director, London 2009.

Szczepański T., Zwierciadło Bergmana, Gdańsk 1999.

Szyjkowska A., Po-twarz. Przekraczanie widzialności w sztuce i filozofii, Gdańsk 2016.

Young B., The Persona of Ingmar Bergman: Conquering Demons through Film, London 2015. 
